\title{
EFFECT OF CHORIONIC GONADOTROPHIN ON THE PRE-IMPLANTATION PERIOD OF PREGNANCY IN RATS
}

\author{
SERGE J. MANTALENAKIS \\ Maternity Hospital 'Alexandra', First Department of Obstetrics and Gynaecology, \\ University of Athens, School of Medicine, Athens 6II, Greece
}

(Received 8th April 1968, revised 25th June 1968)

King (1938) reported that the injection of human chorionic gonadotrophin (HCG) into rats on or before the day of implantation did not interfere with gestation, but that when given after implantation it resulted in the prolongation of pregnancy. Subsequently, Rosenfeld, Lapan \& Baron (1941) confirmed that HCG inhibits parturition, but King's findings concerning the pre-implantation period remain unchallenged. The present work was designed to re-examine the effect of HCG on the pre-implantation stage of pregnancy in the light of the hypothesis that implantation in the rat must be preceded by an 'oestrogen surge' stimulated by gonadotrophins (Shelesnyak, 1960; Psychoyos, 1963; Zeilmaker, 1963).

Nulliparous female Sprague-Dawley rats weighing 180 to $230 \mathrm{~g}$ were placed overnight with either normal or vasectomized males. Pregnancy or pseudopregnancy was inferred from the presence of a vaginal plug early the following day, which was designated Day 1.

In the first experiment the rats were observed near term at 2-hr intervals in order to record the time of parturition and to remove the young. The duration of gestation was about a day longer than in the controls $(P=0.001)$. The mean birth weights of the pups in the experimental and control groups were similar, although the mean number of young born alive was lower in the treated animals (Table 1).

In order to determine whether or not the prolongation of gestation was caused by an inhibition of implantation, twenty pregnant rats, half of which were treated with HCG, were autopsied during the morning of Day 6 and their uterine horns flushed with buffered Ringer's phosphate. Fifty-four blastocysts were recovered from five HCG-treated rats compared with thirteen blastocysts in two controls. All of the blastocysts were in the process of shedding their zonae pellucidae.

In view of these results, the sensitivity of the endometrium following HCG treatment was examined on Days 5 and 6 , either by the induction of deciduoma or by the transfer of blastocysts. Decidual cell reactions were induced on Day 5 or 6 of pseudopregnancy by placing 2-0 cotton (surgical) thread into the left uterine horn from a point near the utero-tubal junction close to the cervix. On Day 9 or 10, the rats were killed and the uterine horns dissected free of 
adherent tissue and weighed individually. The weight of the stimulated horn was divided by that of the control horn to obtain the ratio designated 'decidual response'. The decidual response following stimulation of the uterus on Day 5 in pseudopregnant rats treated with HCG was not significantly different from that in untreated controls. In contrast, stimulation of the uterine horn on Day 6 in pseudopregnant, control animals resulted in a very low decidual response whereas the response in the HCG-treated pseudopregnant rats was considerably higher (Table 2).

\section{TABLE 1}

EFFEGT OF 100 I.U. HUMAN GHORIONIC GONADOTROPHIN GIVEN ON DAY 4 OF PREGNANCY ON THE LENGTH OF GESTATION

\begin{tabular}{|c|c|c|c|c|}
\hline $\begin{array}{c}\text { No. of } \\
\text { rats }\end{array}$ & $\begin{array}{c}\text { Treatment } \\
\text { group }\end{array}$ & $\begin{array}{c}\text { Gestation period } \\
\text { (days; means } \pm S . E .)\end{array}$ & $\begin{array}{c}\text { Mean } \\
\text { no. of young }\end{array}$ & $\begin{array}{c}\text { Mean } \\
\text { weight of young } \\
\text { at birth }(\mathrm{g})\end{array}$ \\
\hline $\begin{array}{l}12 \\
15\end{array}$ & $\begin{array}{l}\text { Treated } \\
\text { Control }\end{array}$ & $\begin{array}{l}23 \cdot 9 \pm 0 \cdot 67^{*} \\
22 \cdot 6 \pm 0.44^{*}\end{array}$ & $\begin{array}{r}8 \cdot 7 \\
10 \cdot 2\end{array}$ & $\begin{array}{l}4 \cdot 79+0.33 \\
4.91+0 \cdot 29\end{array}$ \\
\hline
\end{tabular}

TABLE 2

DECIDUOMA FORMATION IN RATS TREATED WITH 100 I.U. HUMAN CHORIONIC GONADOTROPHIN ON DAY 4

\begin{tabular}{|c|c|c|c|c|c|}
\hline & \multirow[b]{2}{*}{$\begin{array}{l}\text { No. of } \\
\text { rats }\end{array}$} & \multirow[b]{2}{*}{$\begin{array}{l}\text { Treatment } \\
\text { group }\end{array}$} & \multicolumn{2}{|c|}{ Mean weight $(m g)$} & \multirow[b]{2}{*}{$\begin{array}{l}\text { Ratio* }_{B}^{*} \\
B / A\end{array}$} \\
\hline & & & $\stackrel{A}{\text { control horn }}$ & $\stackrel{B}{\text { stimulated horm }}$ & \\
\hline $\begin{array}{l}\text { Uterine stimulation on Day } 5 \text {; } \\
\text { autopsy on Day } 9\end{array}$ & $\begin{array}{l}11 \\
10\end{array}$ & $\begin{array}{l}\text { Experimental } \\
\text { Control }\end{array}$ & $\begin{array}{l}169 \cdot 4 \pm 8 \\
147 \cdot 4 \pm 6\end{array}$ & $\begin{array}{l}1235 \cdot 5 \pm 89 \\
1076 \cdot 2 \pm 78\end{array}$ & $\begin{array}{l}7 \cdot 8 \\
7 \cdot 3\end{array}$ \\
\hline $\begin{array}{l}\text { Uterine stimulation on Day } 6 \\
\text { autopsy on Day } 10\end{array}$ & $\begin{array}{l}12 \\
10\end{array}$ & $\begin{array}{l}\text { Experimental } \\
\text { Control }\end{array}$ & $\begin{array}{l}173 \cdot 7 \pm 13 \\
152 \cdot 9 \pm 7\end{array}$ & $\begin{array}{l}896 \cdot 4 \pm 93 \\
482 \cdot 2 \pm 33\end{array}$ & $\begin{array}{l}5 \cdot 2 \\
2 \cdot 8\end{array}$ \\
\hline
\end{tabular}

* Calculated as the mean of the ratio for each rat.

TABLE 3

IMPLANTATION IN RECIPIENT PSEUDOPREGNANT RATS TREATED WITH 100 I.U. HCG ON DAY 4

\begin{tabular}{r|l|c|c|cc}
\hline $\begin{array}{c}\text { No. of } \\
\text { rats }\end{array}$ & Group & Day of transfer & $\begin{array}{c}\text { No. of blastocysts } \\
\text { transferred }\end{array}$ & \multicolumn{2}{|c|}{$\begin{array}{c}\text { Implantations } \\
\text { No. }\end{array}$} \\
\hline 8 & Experimental & 5 & 59 & 41 & 69 \\
9 & Control & 5 & 67 & 44 & 66 \\
10 & Experimental & 6 & 77 & 39 & 51 \\
9 & Control & 6 & 70 & 2 & 3 \\
\hline
\end{tabular}

Blastocysts were obtained from normal pregnant donors killed on Day 5 . Seven to nine blastocysts were transferred into the left horn of the recipient on either Day 5 or 6 of pseudopregnancy between 09.00 and 12.00 hours. Five days later laparotomy was performed and the number of implantation sites was recorded (Table 3 ). 
These findings suggest that a single injection of HCG given on Day 4 can prolong gestation for about a day in some pregnant rats. Such an effect is due to an extension of the sensitive period rather than to an inhibition of the implantation process. On the other hand, administration of HCG for 7 consecutive days from Day 1 to 7 , did not affect the sensitivity of the endometrium (Mantalenakis, unpublished).

The mechanism by which HCG achieves its effect on uterine sensitivity during the pre-implantation stage remains obscure. Possibly HCG enhances the action of pituitary gonadotrophins at the time of the postulated oestrogen surge or prolongs oestrogen secretion.

\section{REFERENCES}

KING, J. L. (1938) Influence on the duration of gestation of the injection of pregnancy urine extract in the rat before and after implantation. Am. F. Physiol. 122, 455.

Psychoyos, A. (1963) A study of the hormonal requirements for ovum implantation in the rat, by means of delayed nidation-inducing substances (chlorpromazine, trifluoperazine). F. Endocr. $27,337$.

Rosenfeld, S. S., LAPAN, B. \& Baron, H. (1941) Effects of human pregnancy serum on parturition in the rat. Endocrinology, 29, 276.

Shelesnyak, M. C. (1960) Nidation of the fertilized ovum. Endeavour, 19, 81.

ZeILmaker, G. H. (1963) Experimental studies on the effects of ovariectomy and hypophysectomy on blastocyst implantation in the rat. Acta endocr., Copenh. 44, 355. 